\title{
Um huguenote e um católico e a questão da (in)dissolubilidade do matrimônio em Luanda, no século XVII (A Gloriosa Família, de Pepetela, 1997).
}

\author{
A huguenot and a catholic and the issue of marriage (in)dissolubility in \\ Luanda, in the $17^{\text {th }}$ century (A Gloriosa Familia , by Pepetela, 1997).
}

Denise Rocha*

\begin{abstract}
Resumo
O objetivo do estudo é evocar no romance A Gloriosa Família, do angolano Pepetela (1997), a dimensão internacional de um confronto religioso entre a nobreza católica, liderada pelos Guise, e a burguesia calvinista, apoiada pelos Bourbon, que culminou no massacre dos huguenotes, protestantes franceses, na noite de São Bartolomeu (1572), em Paris, e desencadeou a fuga dos sobreviventes para a Holanda e outros países. No "novo romance histórico", que mostra a trajetória da família mestiça Van Dum, nos anos da ocupação de Luanda pelos holandeses (1641 a 1648), em acirrada competição com os portugueses pelos escravos para as plantações de cana-de-açúcar do Brasil, desenrola-se um conflito de fé e dogma entre um huguenote e um católico sobre o casamento: Jean Du Plessis e seu sogro Baltazar Van Dum. O oficial de ascendência francesa, nascido na Niederlande, aportou em Luanda (1641), como membro do exército conquistador e se casou com Matilde que cometeu adultério. Diante dessa tragédia familiar, o marido optou pela ruptura do casamento, que não tem caráter sacramental, segundo a tradição calvinista, e abalou o alicerce católico da ideologia da não dissolução matrimonial. $\mathrm{O}$ artigo, que se baseia na análise bibliográfica, partiu do pressuposto de que a igreja calvinista, criada no contexto da reforma do catolicismo de Roma, desencadeada por Luther (1517), não teria excluído o caráter sacramental e o dogma da indissolubilidade do casamento.
\end{abstract}

Palavras-chave: Literatura angolana; Pepetela; A Gloriosa Família; huguenote; matrimônio.

\begin{abstract}
This study was carried out to call forth in the novel A Gloriosa Família by Pepetela (1997) from Angola, the international dimension of a religious confrontation between the Catholic nobility, led by the Guise, and the Calvinist bourgeoisie supported by the Bourbons, which led up to the slaughter of the Huguenots, French protestants, in Saint Bartholomew's night (1572), in Paris, and its survivals put to flight into the Netherlands and other countries. In the "new historical novel", which shows the course followed by the mestizo Van Dum family in the course of the years of the Dutch occupation of Luanda (1641-1648), the obstinate dispute with the Portuguese concerning slaves meant for sugar-cane plantations in Brazil, a conflict of faith and dogma takes place between a Huguenot and a Catholic on account of a marriage: Jean Du Plessis and his father-in-law Baltazar Van Dum. The officer of French ancestry, born in the Netherlands, arrived at the port of Luanda (1641), as a member of the conquering army and got married to Matilde who committed adultery. In face of such a family tragedy, the husband decided in favor of breaking up his marriage which, according to Calvinist tradition. did not have any sacramental nature, and that shook the Catholic foundations of the marriage indissolubility ideology. The article, based on the bibliographic method, assumes that the Calvinist church created in the context of the reform of Roman Catholicism unleashed by Luther (1517) would not have excluded the sacramental character and dogma of the indissolubility of marriage.
\end{abstract}

Keywords: Angolan Literature; Pepetela; A Gloriosa Família; Huguenot; marriage.

\footnotetext{
${ }^{*}$ Graduada em Letras pela Universidade Estadual Paulista Júlio de Mesquita Filho (UNESP) e doutorado em Letras -Literatura e Vida Social (2005), na UNESP, campus de Assis. Bacharel em História e título de Magister Artium pela Ruprecht- Karls Universität Heidelberg, Alemanha. Atua como docente no curso de Pós-Graduação em Letras da Universidade Federal do Ceará. Bolsista CAPES/PNPD. País de Origem: Brasil. E-mail: dena.maria@outlook.com
}

Horizonte, Belo Horizonte, v. 15, n. 46, p. 543-570, abr./jun. 2017 - ISSN 2175-5841 


\section{Introdução}

Sensual, determinada e com a sexualidade à flor da pele, Matilde, rechonchuda e com olhos azuis, casada com o calvinista Jean Du Plessis, ${ }^{1}$ é a protagonista feminina do clã mestiço católico de Baltazar Van Dum, tema do romance A Gloriosa Família: O tempo dos Flamengos (1997), do escritor angolano Pepetela, que aborda a histórica presença holandesa em Luanda e adjacências, nos anos 1641 a 1648, em busca de escravos para as lavouras açucareiras de Pernambuco.

Grávida de quatro meses, Matilde, que flertava descaradamente em uma época, na qual se exigia recato de moça donzela, e que tinha seduzido um jesuíta, com quem perdera a virgindade, está solteira e desesperada. Seu namorado, o huguenote Jean Du Plessis, oficial do exército holandês, não quer se casar devido às diferenças religiosas. Durante a conversa entre as irmãs católicas, Matilde e Catarina (1644), algumas verdades teológicas vêm à tona:

-Só há uma solução, Matilde. O tenente francês tem de vir pedir a tua mão. Casam e pronto. Quando a barriga aparecer, já estão casados, o pai não poderá fazer nada.

- Não podemos casar. Ele é huguenote.

- Que é isso? [...]

- É uma religião. (PEPETELA, 1999, p. 116).

Ecos de uma guerra santa, de imagens de um cristianismo ocidental dividido e da perseguição católica aos protestantes franceses chegam em Angola, no mês de

\footnotetext{
${ }^{1}$ O romance A Gloriosa Família, de Pepetela, apresenta a trajetória dos filhos legítimos e bastardos de Baltazar Van Dum (1641-1648), inserida no processo colonial comercial e político-militar, financiado pela Companhia das Índias Ocidentais, que tinha o Príncipe de Orange, como chefe de Estado calvinista.

O domínio do calvinismo nas províncias do norte, nos chamados Países Baixos, cuja parte do sul era católica provocou uma separação geográfico-politica. No Tratado de Utrecht (1579) foi constituída uma união das sete províncias protestantes do norte, liderada pela Holanda, para resistir ao domínio espanhol. Foi criada a República ou Estados Gerais, conhecida como a República das Sete Províncias Unidas dos Países Baixos, com sede em Haia, sob liderança militar dos Príncipes de Orange. As províncias católicas do sul, de língua francesa, constituíram a atual Bélgica. No dia 2 de junho de 1621, a Companhia Holandesa das Índias Ocidentais, em Amsterdã, recebeu um alvará com concessão de monopólio de comércio no Caribe e na América do Norte, e para o tráfico de escravos ao Brasil, a fim de acabar com a competição espanhola e portuguesa. O conselho de administração era constituído por 19 membros e, por isso era conhecido como os Dezenove. No ano de 1637, Johann Moritz von Nassau-Siegen (1604-1649) foi nomeado governador das possessões holandesas no nordeste brasileiro que tinham fazendas de cana-de-açúcar.

No mês de maio de 1641, com o objetivo de participar diretamente do tráfico negreiro, Nassau decidiu enviar uma expedição para ocupar Luanda, principal porto de escravos da África Ocidental para o Brasil e, depois, conquistar Benguela, São Tomé e Axim, na costa da Guiné. (MENEZES; SANTOS, 2008, p. 1-5).
} 
janeiro de 1644, relacionados à recusa de Jean Du Plessis em se casar em um “templo papista”. (PEPETELA, 1999, p. 121). Tal fato ocorreu 72 anos depois do massacre dos huguenotes na Noite de São Bartolomeu, em Paris (1572), que provocou a fuga deles, inclusive a de familiares de Jean, que nasceu no exílio em Flandres (região da atual Holanda e Bélgica), engravidou uma filha da tradicional família católica dos Van Dum, em Luanda, casou-se e foi traído.

No romance A Gloriosa Família, de Pepetela, a questão do ideário religioso do casamento, sob a perspectiva de um huguenote, Du Plessis, marido traído, e de um católico, Baltazar Van Dum, sogro defensor da honra familiar, se sobressaem em um modelo colonial no qual o português impôs o cristianismo de Roma e um dos seus dogmas: o sacramento da instituição do matrimônio e sua indissolubilidade.

O presente estudo, de caráter bibliográfico e em diálogo com outras artes (pintura e moeda comemorativa), partiu da reflexão sobre a extensão radical do acima referido dogma católico, que não faz parte dos pressupostos da religião criada por Jesus Cristo, segundo o Novo Testamento, mas, sim, foi elaborado no Concílio de Trento (1545-1563). Além do mais, o tema do calvinismo colonial em regiões católicas e o das querelas, motivadas pela intolerância religiosa, é pouco conhecido e pouco estudado, seja na pesquisa histórica ou literária.

A análise literária enfatiza o conflito de duas formas teológicas europeias de visão de mundo, o catolicismo e o calvinismo, que refletem um período conturbado da história das ideias antagônicas no seio do cristianismo, no século XVI. Tal tipo de guerra santa causou mortandade na França, motivou fugas, foi levada para confrontos nas colônias de além-mar e foi um dos temas do romance de Pepetela, A Gloriosa Família, que cristalizou na esfera artística o alcance do fanatismo religioso, pois a igreja calvinista excluiu o caráter sacramental do matrimônio, dogma basilar do catolicismo. 


\section{Huguenotes: os protestantes franceses e as Guerras de Religião (1562-1598)}

Conspirações, rebeliões, peste, guerras, fome e forças da natureza eram tipos de medos que assolavam a mentalidade europeia, paralelamente ao desenvolvimento e apogeu do Renascimento, nos séculos XV e XVI. Outros temores eram: a ideia do Juízo Final, e a do satanás e seus ajudantes (a mulher, as bruxas e os judeus). Nesse contexto de incertezas, Martin Luther (1483-1546), monge agostiniano e professor de teologia, discordou da doutrina católico-romana de que o perdão divino poderia ser alcançado por meio da compra das indulgências, e pregou na porta da Igreja de Wittenberg, atual Alemanha, no dia 31 de outubro de 1517, as famosas 95 teses que continham severas críticas ao papado. (OHLIG, 1987, p. 139). Uma das teses afirmava que somente a fé assegurava a salvação. A ruptura com Roma tinha iniciado.

Os seguidores de Luther fundaram igrejas luteranas, e as igrejas reformadas ou presbiterianas foram criadas por Jean Calvin (1509-1564)² na Suíça e na França. Os calvinistas franceses foram denominados de huguenotes, palavra originada do alemão Eidgenossen (colegas de juramento). (BRIGGS, 1996, p. 136).

No ano de 1559 ocorreram dois fatos importantes na França:

1) os católicos Guise exigiram do novo rei, o jovem François II (1544-1560), o controle do exército, da igreja, da política externa e das finanças do estado. Indignados, os Châtillon e os Bourbonen se uniram à rica burguesia calvinista para acabar com o poder dos Guise que apoiavam o rei Filipe II da Espanha, um grande inimigo da França;

2) a realização de um sínodo dos huguenotes (10\% da população), em Paris (BRIGGS, 1996, p. 136), foi entendida como uma provocação, pois a prática do

\footnotetext{
${ }^{2}$ Crítico da igreja da França, Calvin foi perseguido e refugiou-se em Genebra (Suíça), onde instituiu uma ditadura teocrática que pregava a predestinação, mantinha os sacramentos católicos (batismo e eucaristia) e afirmava que a fé, outorgada por Deus às pessoas, proporcionava a salvação. Tal movimento religioso radical, denominado de calvinismo, valorizava o trabalho como forma de justificativa para a obra criadora de Deus, estimulando a acumulação do capital e a prática da usura, em busca do progresso do ser humano. Esses valores éticos calvinistas se ajustavam aos interesses da burguesia capitalista. (GOMES, 2002, p. 1-20).
} 
protestantismo estava proibida por lei. François II reinou menos de dois anos e foi sucedido por Charles IX (1550-1574), que, inicialmente, promulgou dois éditos em prol dos calvinistas, mas depois permitiu o acirramento da intolerância contra eles, autorizando a matança de 1572, em Paris.

O complexo entrelaçamento de fatores internos franceses e sua dimensão europeia, acentuado pela questão religiosa e pela perseguição tolerada inicialmente pelo rei François I (1494-1547), que foram atenuadas com as suas publicações do Édito de Orleans (1561) e do Édito de Saint-German, de 17 de janeiro de 1562, no qual os direitos dos huguenotes foram reconhecidos pela primeira vez. Esses atos foram considerados como traição pelos católicos. (DELUMEAU, 1989, p. 249). No entanto, a rivalidade entre os católicos e os calvinistas ${ }^{3}$ não terminara e foram desencadeados atos violentos contra os huguenotes em várias regiões do país. 4

Em 18 de agosto de 1572, o anúncio do casamento da princesa católica francesa, filha de Catarina de Médici e do rei falecido Henri II e irmã do rei Charles IX, Margarete de Valois, com Henrique, rei de Navarra (1553-1610), líder huguenote, sinalizou uma trégua que durou pouco tempo.5 Os católicos Guise desconfiaram dos objetivos da união.

\footnotetext{
${ }^{3}$ Grupos de huguenotes provocaram muitos distúrbios contra os católicos e as igrejas francesas. No ano de 1562, em Rouen, Gien e Lyon (catedral de Saint-Jean), os templos sofreram ataques com destruição de imagens e quadros sacros. Na Niederlande, os calvinistas também agiram com violência: No dia 10 de agosto de 1566, cerca de 15000 pessoas foram incitadas pelos sermões de um pastor, que exigia atos de iconoclastia, isto é, contra a veneração de ícones e imagens religiosas. Eles foram de Valenciennes até Antuérpia, e destruíram igrejas e capelas, crucifixos e quadros sacros, altares e toalhas, órgãos, cadeiras, livros, etc. Alguns se apossaram de objetos de ouro das igrejas e os derreteram. Em 27 de agosto do mesmo ano, na região de Edingen, huguenotes de Oudenaarder se reuniram em Heerhouw e atacaram a igreja dos cátaros, na hora da comunhão, devastando os altares e os livros da biblioteca. (DELUMEAU, 1989 , p. 260, 266 e 261).

${ }^{4} \mathrm{Na}$ cidade de Rouen (1560), durante uma procissão católica, huguenotes que a observavam pelas janelas de suas residências, mas não demonstraram reverência, tiveram seus domicílios invadidos e destruídos. (DELUMEAU, 1989, p. 260). Em Wassy (Lothringen), no dia 1 de março de 1562, durante uma missa dos huguenotes, que não tinha sido autorizada, companheiros do Duque François de Guise mataram um elevado inúmeros de participantes. (BRIGGS, 1996, p. 136). Em Toulouse (1562), o padre da catedral exigia jejuns dos católicos, por causada ameaça dos huguenotes, bem como previa que as casas dos hereges, inclusive algumas dos funcionários de alto padrão, seriam invadidas pela cólera de Deus.

Em Orange (fevereiro de 1571), monges medicantes incentivaram os 11 dias do massacre. Em Orleans, Sorbin, padre real, atacou casas de protestantes. (DELUMEAU, 1989, p. 260).

${ }^{5} \mathrm{~A}$ rainha Caterina acreditou que, a realização de um matrimônio católico-huguenote, poderia acabar com as guerras religiosas que se pautaram por depredações, estupros e assassinatos, desde 1562. A cerimônia religiosa do casamento entre Margarete e Henrique foi realizada em um palco sobre o rio Sena, montado diante do portal ocidental da catedral, pois o noivo não podia entrar no templo católico. (RAMME, s.d., on-line).
} 
No dia 22 de agosto, em rua aberta, ocorreu um atentado a Gaspar de Coligny (1519-1572), líder huguenote, depois de uma visita ao seu amigo, o rei Charles IX. O ato criminoso praticado pelo jovem católico Maurevert agudizou o conflito, pois os calvinistas temeram por uma conspiração de maior alcance. Pela manhã do dia 23 de agosto, nas missas parisienses, padres falavam nos púlpitos sobre um planejado atentado sobre o católico Henri de Guise, e incitavam a ira popular que foi aumentada por causa de dois falsos boatos: a fuga de Guise de Paris e a marcha das tropas de Montmorency, suposto huguenote, para a capital. (DELUMEAU, 1989, p. 249)

O matrimônio entre Margarete (Margot) e Henrique de Navarra se realizou no dia 24 de agosto, no período verpertino. O rei Charles IX, irmão da noiva, sob pressão de sua mãe, Caterina de Médici, ordenou o massacre a Coligny e aos huguenotes na noite depois das bodas: Armas foram dispostas para a defesa do rei, da prefeitura e da cidade de Paris, como defesa da suposta conspiração huguenote. (DELUMEAU, 1989, p. 250).

Os sinos da igreja de St. German-l'Auxerrois começaram a tocar já na passagem da noite de 23 e 24, como sinal para o ataque noturno que ocasionou o sangrento episódio conhecido como a noite de São Bartolomeu de 1572: O extermínio cruel de cerca de 3000 pessoas e o assassinato de Coligny, por ordem do Duque de Guise, Henri de Lorraine. O corpo foi defenestrado, decapitado, jogado no rio Sena, pescado e pendurado pelas pernas na forca.

A matança se espalhou por Rouen, Lyon, Orleans e Toulose (BRIGGS, 1996, p. 135). Religiosos -franciscanos, capuchinhos, carmelitas e dominicanosestimulavam os católicos e deram sinal para os massacres. Na cidade de Bordeaux, no dia 20 de setembro de 1572, o jesuíta E. Auger anunciou a chegada do Anjo Exterminador e incitou a violência que culminou com um massacre no dia 3 de 
outubro. (DELUMEAU, 1989, p. 259 e 260). A carnificina desenfreada provocou a diáspora dos sobreviventes para a Holanda e outros países. ${ }^{6}$

Figura 1 - O Massacre no dia de São Bartolomeu

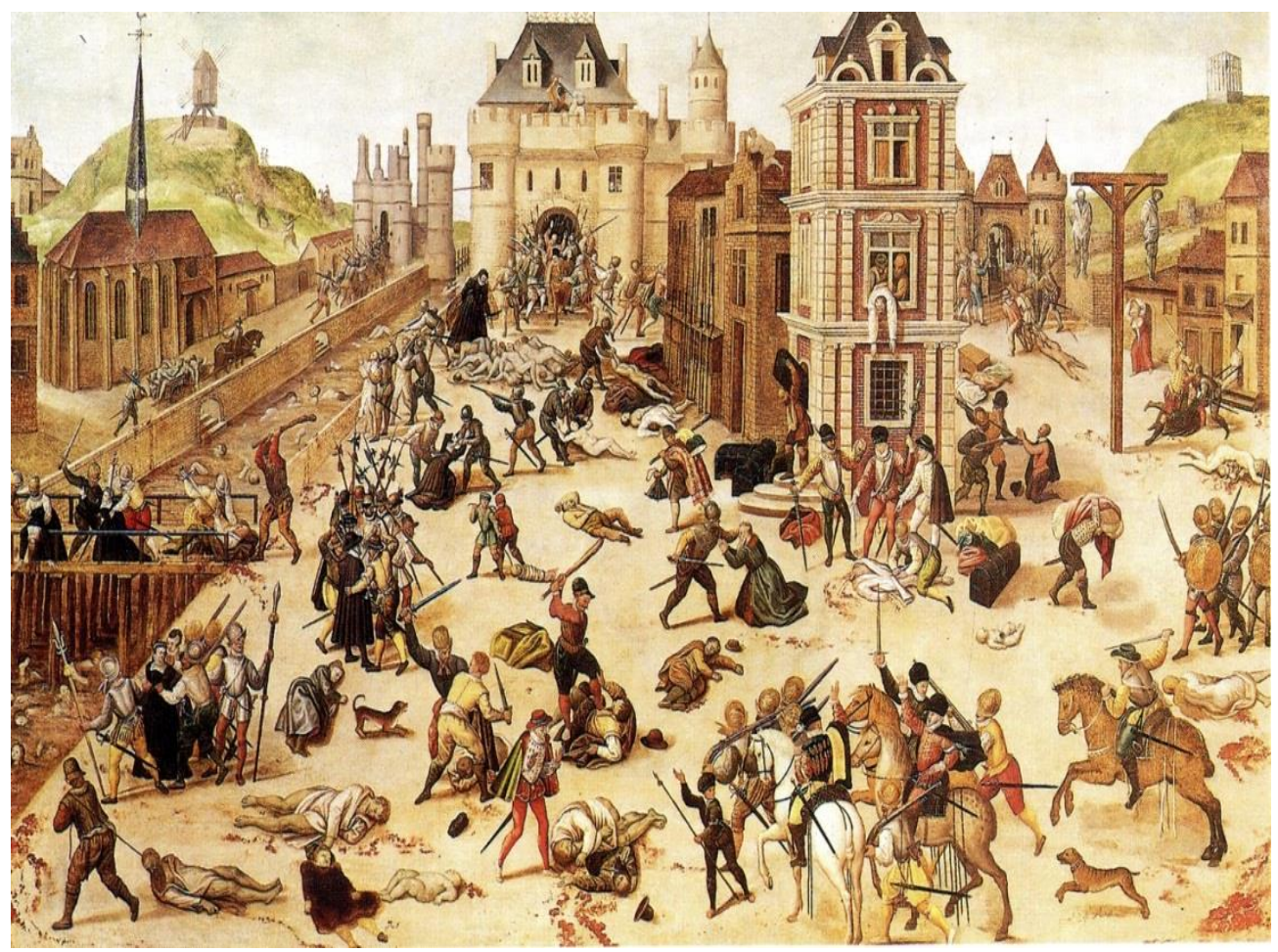

Fonte: François Dubois.7

Por causa do massacre dos huguenotes, considerados infiéis, o papa Gregório XIII (1502-1585) enviou ao rei Charles IX uma condecoração - a Rosa de Ouro -, encomendou uma missa Te Deum, para ser cantada em ação de graças: Uma tradição que foi mantida por muitos anos. Além disso, mandou cunhar uma moeda com sua efígie e anjos com espada na mão, matando os inimigos da fé, com a frase Ugonottorum strages. (MASSACRE, s.d., on-line).

\footnotetext{
${ }^{6}$ Um grupo de huguenotes chegou à baía da Guanabara, região sem controle luso, no dia 7 de março de 1557, como parte do reforço solicitado ao rei pelo católico Nicolas de Villegagnon para colonização dessa região sul-americana que estava em poder dos portugueses, segundo determinação do Tratado de Tordesilhas (1494).

${ }^{7}$ A pintura a óleo Massacre de São Bartolomeu (94 x $154 \mathrm{~cm}$ ), que se encontra no Museu Cantonal de Lausanne, foi o único quadro do huguenote François Dubois que sobreviveu ao tempo. Não se sabe se ele presenciou a matança, mas o cirurgião Antoine Dubois, seu parente, morreu no extermínio. O pintor fugiu para Lausanne e o quadro sobre o terrível acontecimento, que foi encomendado por um banqueiro de Lyon, mostra dois pormenores: Catarina de Médici, com roupa negra, que surge do Louvre e observa a pilha de corpos (bem atrás, à esquerda), e o corpo de Gaspar II de Coligny, líder huguenote, de camisa branca, pendurado em uma janela (centro, à direita). (DUBOIS, s.d., on-line).
} 
Figura 2 - Moeda comemorativa da matança dos huguenotes.

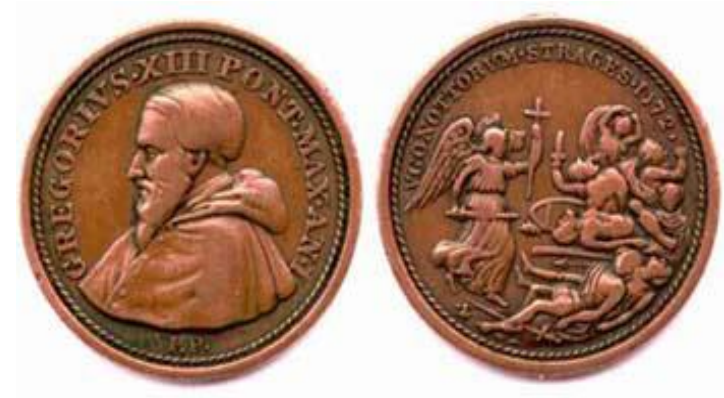

Fonte: Carlos Mello

O papa Gregório XIII encarregou ainda Giorgio Vasari de pintar um mural sobre o episódio. (MELLO, 2012, on-line).

Figura 3 - O Mural de Vasari.

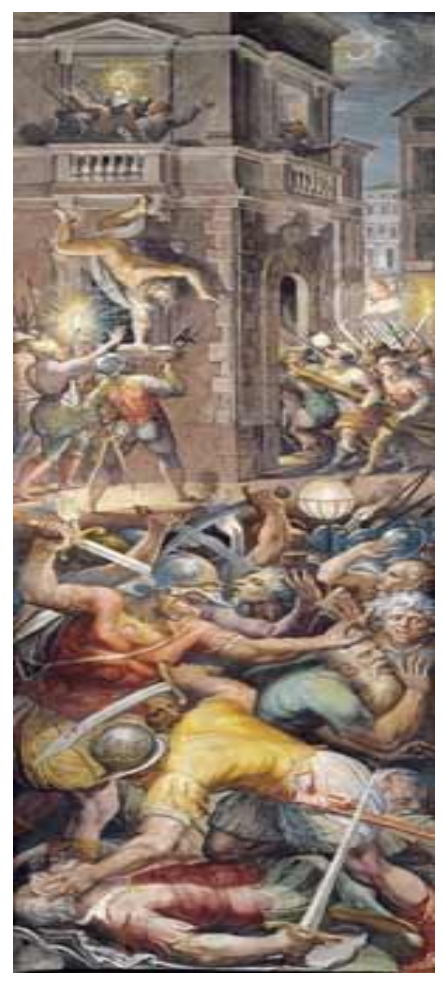

Fonte: Giorgio Vasari (1572-73)

Henrique, rei de Navarra, sobreviveu à matança de São Bartolomeu (1572) nos aposentos reais. Ele teve que renunciar ao calvinismo e foi encarcerado no Louvre durante o reinado de Henri III (1574-1589), seu cunhado. 
No ano de 1576, ele conseguiu regressar à sua terra, depois de uma fuga durante uma caçada real, e, anos mais tarde, Henrique, que se manteve fiel ao catolicismo, retornou à França (1589), foi coroado rei (Henri IV) e promulgou o Édito de Tolerância de Nantes (1598), que concedia igualdade de direitos políticos aos huguenotes. Defensor da coesão interna, Henri IV, que teria dito "Paris vale uma missa”, declarou: "A França não se dividirá em dois países, um huguenote e outro católico. Se não forem suficientes a razão e a justiça, o rei jogará na balança o peso da sua autoridade”. (RAMME, s.d., on-line).

O conflito religioso entre católicos e huguenotes, que culminou no massacre na noite de São Bartolomeu (1572) e motivou fugas para outros países, teve reflexos na literatura francesa: A Rainha Margot, de Alexandre Dumas (1845), que foi adaptado ao cinema com o nome Intolerance (1916), de D. W. Griffith e, posteriormente, com título original (1994), sob direção de Patrice Chéreau; Os Pardaillans, de Michel Zevaco (1860-1918) e Rouge Brésil, de Jean-Christophe Rufin (2001). Além de As aventuras de três adolescentes huguenotes fugindo à perseguição, do holandês A. Van der Jagt (2001).

Em Angola, o romancista Pepetela publicou A Gloriosa Família: O tempo dos Flamengos (1997) que tem um episódio sobre a questão do matrimônio, segundo a perspectiva de um huguenote e a de um católico. 8

\section{0 casamento segundo a teologia católica e a teologia protestante}

A ética do matrimônio judaico-cristão é baseada em uma concepção teológica do Antigo Testamento, que institui que na relação entre um casal: "os dois serão um só carne”. (Gênesis 2, 23 e 24). 9

\footnotetext{
8 Os huguenotes foi tema de uma ópera homônima de Giacomo Meyerbeer (1791-1864), com libreto de Éugene Schrieber e Émile Deschamps (1836). No Brasil foi apresentada, no Cine Íris, no Rio de Janeiro, a opereta Os huguenotes, de Octávio Rangel e música de Carlos Carvalho. (OS HUGUENOTTES, 1926, on-line). Foram feitas algumas pinturas sobre o assunto: Massacre de São Bartolomeu, de François Dubois (1529-1584), Preparação para a noite de São Bartolomeu, de Karl Fedorovich Gun (1830-1877), Afresco sobre a Noite de São Bartolomeu, de Giorgio Vasari (1511-1574), e Uma manhã nos portões do Louvre (1889), de Édouard Debat-Ponsan (18471913).
} 
A união religiosa entre uma mulher e um homem constitui a base da família - pais e filhos - e tem implicações sociopolíticas, religiosas e econômicas. Observase, no entanto, que as relações entre o casal, desde tempos imemoriais, eram assimétricas e que tal situação ainda perdura em muitos casamentos na atualidade que são pautados no poder patriarcal e na submissão feminina.

A situação pouco valorativa da mulher remete à tradição da sociedade judaica anterior ao cristianismo, segundo consta em textos do Antigo Testamento que acentua o valor inferior da mulher (Levítico XXVII, 1-4) ${ }^{10}$ e seu altruísmo em prol da família (Provérbios XXXI, 10-31) ${ }^{11}$.

O casamento de tradição judaico-cristã foi considerado na teologia católicoromana um sacramento, ${ }^{12}$ embora segundo o texto sagrado do cristianismo, o Novo Testamento, Jesus instituiu em sua igreja somente dois sacramentos: o Batismo (sacramento de iniciação)13 e a Ceia do Senhor (sacramento da eucaristia). No entanto, com o passar dos séculos em alguns sínodos foram introduzidos alguns dogmas e sacramentos ${ }^{14}$ que serviram como base para o catolicismo romano. No Concílio de Trento (1545-1563), conhecido como o movimento da Contra-Reforma, foi instaurado um novo sacramento, o do casamento, que seria perpétuo, isto é, a

\footnotetext{
${ }^{9} 23$ Disse então o homem: "Esta, sim, é osso dos meus ossos/ e carne da minha carne!/ Ela será chamada mulher,/ porque do homem foi tirada". / 24 Por essa razão, o homem deixará pai e mãe e se unirá à sua mulher, e eles se tornarão uma só carne. (ANTIGO, s.d., online).

${ }^{10} 1$ Disse também o Senhor a Moisés: 2 "Diga o seguinte aos israelitas: Se alguém fizer um voto especial, dedicando pessoas ao Senhor, faça-o conforme o devido valor; 3 atribua aos homens entre vinte e sessenta anos o valor de seiscentos gramas de prata, com base no peso padrão do santuário; 4 e, se for mulher, atribua-Ihe o valor de trezentos e sessenta gramas. (Levítico XXVII, 1-4). Idem, ibidem.

${ }^{11}$ A esposa de carácter nobre. 10 defenda os direitos/ dos pobres e dos necessitados. Uma esposa exemplar;/feliz quem a encontrar!/ É muito mais valiosa que os rubis. [...] / 25 Reveste-se de força e dignidade;/ sorri diante do futuro. [...] 26 Fala com sabedoria e ensina com amor./ 27 Cuida dos negócios de sua casa/e não dá lugar à preguiça./28 Seus filhos se levantam e a elogiam;/ seu marido também a elogia, dizendo:/ 29 "Muitas mulheres são exemplares,/ mas você a todas supera". /[...]. Idem, ibidem.

${ }^{12} \mathrm{Na}$ obra Sumário da Doutrina Cristã, de Edward W. A. Koehler, é esclarecido que o termo sacramento designava originalmente, em latim, um solene juramento como o de um soldado, bem como no português antigo que posteriormente incluiu o sentido de um adjetivo sacramental como sinônimo de cerimonioso. O termo, entretanto, que não aparece na Bíblia, começou a ser utilizado vinculado ao batismo. Nessa cerimônia o adepto jurava fidelidade a Deus e renunciava aos ídolos pagãos. (KOEHLER apud BERGSTEDT, 2010, on-line).

${ }^{13} \mathrm{O}$ batismo ou purificação foi estabelecido por Jesus Cristo (Evangelho de João (3, 25 e 26), de Mateus (final) e de Marcos (7, 4)).

${ }_{14}$ No Concílio de Trento (1545-1563) foram instituídos alguns dogmas como aquele dos sete sacramentos: o batismo, a crisma (confirmação), a eucaristia, a reconciliação (penitência), a unção dos enfermos, a ordem (autoridade eclesiástica) e o matrimônio. (OS SETE SACRAMENTOS, s.d, on-line).

Esse concílio, realizado na cidade italiana de Trento, no Tirol italiano, foi considerado o mais longo da história. Convocado pelo Papa Paulo III, como um ato de mudanças na Igreja e Roma, o concílio emitiu vários decretos disciplinares e especificou doutrinas católicoromanas, para assegurar e fortalecer a fé e a disciplina eclesiástica na época da reforma protestante.
} 
união teria duração até a morte de um dos cônjuges. O ideário da indissolubilidade do matrimônio no catolicismo foi o resultado desse concílio do século XVI.

Angelo Scola, Arcebispo-Patriarca de Veneza, em $O$ mistério nupcial, com base na antropologia, menciona a ideia da sacramentalidade, mas faz algumas ressalvas:

O matrimônio monogâmico e indissolúvel pertence ao dado antropológico original. Esta afirmação não perde seu valor diante das diversas concepções culturais e históricas do matrimônio que não se atenham a estes dois parâmetros. Com efeito, afirmando que o matrimônio monogâmico e indissolúvel é um dado antropológico original, não se esquece que na história o ideal não é sempre concretamente vivido. (SCOLA, 2003, p. 216).

Scola acentua que a família que "pode ser considerada uma dimensão fundamental da sociedade" é “a união entre um homem e uma mulher, necessariamente referida à geração de filhos e publicamente reconhecida pelo contrato matrimonial”. O religioso acrescenta ainda que o pacto religioso firmado entre um casal "não pode ser sufocante" e que é "uma condição necessária à verdade do outro [...] o tornar-se uma só carne não anula esta exigência de verdade de cada um”. (SCOLA, 2003, p. 211 e 216).

Esse sacerdote, cujo papel na hierarquia católico-romana é imenso, pois se trata de um Arcebispo- Patriarca, questiona a tradição judaico-cristã, na qual a mulher tem valor subalterno no casamento e, por isso, muitos relacionamentos celebrados na igreja são a base de infelicidade para a família. E, apesar disso, eles não costumam ser rompidos, com o argumento de que a separação traria problemas para os filhos, bem como no da indissolubilidade sagrada do matrimônio, além das implicações econômicas.

Fato é que o divórcio na tradicional família católica é inadmissível e que os separados não podem comungar, receber a hóstia, ou seja, participar da cerimônia da ceia do Senhor, rememorada e celebrada na missa católica. A exclusão de católicos nesse rito evoca a concepção do caráter sacramental do casamento que 
não existe na teologia protestante, de tradição calvinista, conhecida como renovada.

No ideário religioso protestante compreende-se que o sacramento é "uma santa ordenança instituída por Cristo em sua Igreja, para significar, selar e conferir aqueles que estão no pacto da graça”. O matrimônio não seria, portanto, um meio de graça, os quais são três - a Palavra, a Oração e os Sacramentos -. Tais ensinamentos estão no Catecismo Maior da igreja protestante de tradição calvinista. (IGREJA, 1991, p. 349 e 347).

Calvino, na obra Instituição da religião cristiana, contesta o caráter sacramental e da indissolubilidade do matrimônio, conforme preconizado pela teologia católica romana, ao afirmar que:

O último sacramento que enumeram é o matrimônio. Se bem que todos admitem que tem sido instituído por Deus; porém, também os ofícios dos trabalhadores são bons, sapateiros, bombeiros, os quais, sem embargo, não são sacramentos. Porque não somente se requer para que haja sacramento que seja obra de Deus, é necessário ainda que exista uma cerimônia externa, ordenada por Deus, para confirmação de alguma promessa. (CALVINO apud MAGALHÃES FILHO, s.d., p. 7).

Em relação à “celebração externa, ordenada por Deus”, à união entre duas pessoas, Shirley C. Guthrie Jr., no artigo Para uma teologia do casamento cristão, afirma que: “o casamento cristão é uma parceria de vida fundamentada no amor mútuo em fidelidade a Deus, confirmada e igualmente atestada por uma cerimônia de casamento, e mantida na dependência do perdão de Deus e graça capacitadora de Jesus Cristo”. Na “parceria de vida”, que envolve sinceridade, transparência, cumplicidade e sexualidade: "Deus não efetua o casamento; duas pessoas é que o fazem”. Nessa perspectiva, o matrimônio está mais relacionado com o indivíduo do que com a sociedade, embora a celebração tenha caráter coletivo: “o casamento é um assunto social e comunitário, e não simplesmente particular e pessoal, e a cerimônia de casamento é o reconhecimento, aceitação e compromisso públicos desse fato”. (GUTHRIE JR., 1998, p. 288, 289 e 291). 
A teologia protestante possibilita a separação do casal: "Portanto, um casal pode, algumas vezes, decidir corretamente que o divórcio não significa nenhuma dissolução do casamento, mas o reconhecimento de que ele nunca existiu ou de que ele não existe mais ou, ainda, de que ele não pode tornar-se um verdadeiro casamento”. (GUTHRIE JR., 1998, p. 291).

Conforme já mencionado acima, a perspectiva calvinista retira o caráter sacramental do matrimônio e a ideia da sua indissolubilidade, em contraposição ao ideário defendido pela tradição católica romana. O choque dessas duas cosmovisões religiosas é constatado nas relações entre o huguenote Jean Du Plessis e o católico Baltazar Van Dum em Luanda, no século XVII, por causa do comportamento imoral da jovem esposa e mãe Matilde.

\section{Adultério feminino, honra masculina e luta pela (não) preservação da união conjugal}

O conflito transatlântico entre Recife (Brasil holandês) e Salvador (Brasil luso) em Luanda pela mão de obra escrava para a agricultura canavieira sulamericana é o tema principal do romance A Gloriosa Família: o tempo dos flamengos, ${ }^{15}$ do escritor angolano Pepetela (Artur Carlos Maurício Pestana dos Santos), que foi agraciado com o Prêmio Camões 1997. O autor apresenta na obra caracterizada, como "metaficção histórica”, ${ }^{16}$ uma etapa da história angolana (16411648), sob a perspectiva de um escravo, mudo de nascença, presenteado a Baltazar Van Dum pela rainha Jinga do Dongo e de Matamba, detentora do tráfico de escravos.

\footnotetext{
${ }_{15}$ Dividida em 12 capítulos com informações, em parênteses, sobre mês e ano do ocorrido a ser narrado, por exemplo (Capítulo Primeiro (Fevereiro de 1642)), o romance tem um prólogo sobre um episódio histórico envolvendo Van Dum, narrado por António de Oliveira Cadornega em História Geral das Guerras Angolanas (1680). Um glossário, anexado ao final, contém 42 palavras, em sua maioria no idioma kimbundi, relativas à fauna, flora, cultura e religião nativa.

${ }^{16}$ A partir da década de 1980, para separar, surgiu um tipo de produção literária denominada de "novo romance histórico", o qual, com caráter de metadiscursivo, refletia uma tentativa crítica de reescrita da historiografia oficial que apresentava a versão do colonizador. Por meio da ironia, da paródia e da intertextualidade, os escritores de narrativas de fundo histórico enfatizam o discurso do oprimido, do "ex-cêntrico", que enfrenta os mecanismos do poder ("metaficção historiográfica"). (HUTCHEON, 1991, p. 13-14; 250). O narrador de A Gloriosa Família é um escravo.
} 
Em Pepetela e as (novas) margens da nação angolana, Inocência Mata escreveu sobre afinidades temáticas dos romances históricos do autor ("narrativas de fundação”):

que se aproximam pela textualização de traços primordiais - a saber, Yaka, 1984/1985, Lueji. O Nascimento de um Império, (1989), e $A$ Gloriosa Família. O Tempo dos Flamengos, (1997)- são campo fértil para o desvelamento do seu projeto discursivo de nação, da luta narrativa na sua escrita (da nação) a partir de narrativas de fundação como são as três obras supracitadas. (MATA, 2001, p. 139-140).

O narrador onisciente de A Gloriosa Família era filho de uma escrava lunda e de um capuchinho italiano, e atuava como o pajem-mor do flamengo negreiro. Ele narra o cotidiano da vida do católico Baltazar Van Dum, de forma humanizada, mostrando as fragilidades e contradições dos membros da sua família: oito filhos legítimos com a esposa oficial Inocência (Gertrudes, Matilde, Rosário, Ana, Rodrigo, Ambrósio, Benvindo e Hermenegildo), três reconhecidos (Nicolau, Catarina e Diogo) e inúmeros anônimos, na Europa, na sua sanzala (propriedade rural), perto de Luanda, e outros na quinta no rio Bengo.

O romance delineia a vida da dinastia mestiça Van Dum, na cidade de Luanda e região, nos anos 1641 a 1648, época da colonização holandesa, representante dos interesses da Companhia das Índias Ocidentais. Nessa época, as mulheres católicas e aquelas das diferentes etnias locais tinham um papel social muito claro: preservar a virgindade física até a consumação do matrimônio; satisfazer o cônjuge sexualmente na condição submissa e zelar pela integridade física e moral das filhas, perpetuando um ciclo ancestral de repressão erótica feminina.

Matilde Van Dum, diferentemente de suas irmãs - Gertrudes, Rosário, Ana e Catarina -, faz o que quer para sentir prazer, não respeitando o voto de castidade de um padre, tampouco os sagrados laços do matrimônio e da maternidade. 
Além de ser vaidosa e independente, a moça se envolvia nas conversas sobre política que o pai tinha frequentemente com os filhos Rodrigo, Ambrósio, Benvindo e Hermenegildo.

No momento da invasão holandesa em Luanda, no período final do reinado dos Filipes da Espanha em Portugal (1640-1641), a situação entre os lusos e os holandeses deveria se normalizar, pois nunca tinham sido inimigos. No entanto, um novo tratado não tinha sido ainda validado e, por isso, ela questionou o pai: “Como vamos ficar, quando esse acordo for válido? - perguntou Matilde, de olhos azuis brilhantes quando certos temas eram atirados para a mesa". (PEPETELA, 1999, p. 26).

\subsection{Calvinistas em Luanda}

A Holanda do século XVI se tornou local de refúgio para os calvinistas franceses que se fixaram e tiveram filhos, como no caso da família de um dos personagens de A Gloriosa Família, o huguenote Jean Du Plessis, nascido em Flandres. Para escapar do radicalismo religioso dos pais, ele se alistou no exército holandês e aportou em Luanda na função de tenente.

Na narrativa angolana dois mundos se contrapõem, segundo a interpretação de pessoas com cosmovisão cristão diferenciada: de um lado, o católico-português que denomina o diferente como "herege" e, de outro, o calvinista-holandês que caracteriza o estranho como "papista”.

No dia 25 de agosto de 1641, vinte navios holandeses, oriundos de Recife, Pernambuco, sob a administração de Nassau, chegaram em Luanda, colonizada pelos portugueses, desde o início do século XVI, e provocaram tumulto, conforme o narrador-escravo: "O meu dono e nós todos fomos para a cidade alta, fugindo aos hereges protestantes e calvinistas. [...] Se perderam muitas riquezas, todas caídas 
nas mãos daqueles anti-Cristos calvinistas". (PEPETELA, 1999, p. 20 e 40). Posteriormente, o governador Menezes, civis, religiosos e escravos debandaram para o sertão próximo e, depois, se instalaram em Massangano, vila lusa construída ao lado da fortaleza-presídio, localizada na confluência dos rios Kwanza e Lucala.

Enviados por Maurício de Nassau, administrador do Brasil Holandês, os funcionários administrativos e militares da Companhia das Índias Ocidentais, a qual financiava o exército para suas empreitadas comerciais de além-mar, ocupou a vila portuguesa e tentava organizar o comércio negreiro.

O mentor religioso, conhecido como predikant, representava a linha calvinista e suas medidas radicais de contenção de emoções mundanas, sempre criticando o comportamento inadequado dos militares em relação aos jogos de baralho a dinheiro, entre outros aspectos:

os tratava a todos por devassos por andarem atrás das negras e por gastarem fortunas em roupas caras e outros luxos, o que aliás nem era verdade, bastava um aparecer com um dólman mais elegante para o pregador o apostrofar de pecador e corrupto. (PEPETELA, 1999, p. 34).

O predikant reprovava o uso de jóias e de adornos de metais preciosos, utilizados pelos "hereges amantes da luxúria”. O Secretário Croesen, um "calvinista fanático", segundo os católicos, ia além e criticava os "sacrílegos papistas" e os objetos religiosos das igrejas católicas, banhados em ouro e prata:

-Sacrilégios! A verdadeira religião não aceita esses ídolos do demónio, esse luxo e ostentação das igrejas papistas. Seria uma medida muito santa apanhar esses objectos todos e fundi-los. A prata e o ouro devem servir para outros fins, não para decorar lugares de culto. O incorruptível Calvino ensinou isso. (PEPETELA, 1999, p. 37).

Muitos calvinistas civis e militares, que viviam em Luanda, não eram praticantes convictos da religião protestante. No entanto, o diretor Hans Molt professava a crença, visceralmente e, por isso, a sua transferência para Recife foi sentida "para desespero do predikant, deixado para trás no meio de bárbaros 
bebedores de vinho, sem a superior protecção de um director temente a Deus”. As mudanças foram radicais: “Agora quem mandava era Redinckove e o predikant estava na mó de baixo”. (PEPETELA, 1999, p. 185 e 195).

Muito próxima à Luanda, se localizava a ilha com o mesmo nome que pertencia ao rei congolês. O governador insular foi no Congo buscar um religioso e retornou com um capuchinho italiano, padre Mateus, fato que provocou a fúria do líder protestante:

O predikant deve ter chorado baba e ranho a tentar convencer os directores da Companhia do perigo de permitir a existência de um papista tão perto da cidade. Mas a Ilha era território do Kongo e este era um importantíssimo reino aliado. O predikant só podia gastar lenços a assoar-se e lançar indirectas viperinas nos sermões do culto calvinista. Sem resultado. O padre Mateus fazia repicar os sinos das três igrejas da ilha às mesmas horas. Se ouviam os sinos na cidade, para desespero do predikant, que tapava os ouvidos com bolas de cera. E aos domingos alguns membros da família Van Dum atravessavam o canal para assistir à missa na Ilha. (PEPETELA, 1999, p. 81).

\subsection{De namoro a casamento: um interlúdio católico-huguenote}

Nessa sociedade seiscentista, dividida entre católicos e calvinistas, se desenrola um drama afetivo entre a jovem casadoira, Matilde Van Dum, afoita e sensual, e o tenente Jean du Plessis, tímido e inseguro. Sedutora e determinada, durante as bodas de seu irmão Rodrigo com Nzuzi, ela escolhera como namorado o huguenote:

As mulheres se colocaram de um lado, sentadas sobre esteiras, e os homens conversavam em grupos, afastados delas. Mas Matilde estava no meio de uma roda de oficiais mafulos, treinando o flamengo que aprendera com o pai, como nós todos. Fui observando esse grupo e logo distingui o que devia ser o tenente Jean Du Plessis. Se todos comiam Matilde com os olhos, esse oficial estava mais derretido que os outros e ela o mirava de vez em quando de maneira especial Jean Du Plessis, se as minhas deduções não estivessem erradas, o que dificilmente sucede, era o mais baixo do grupo. Moreno, mas mais branco que os portugueses. Tinha barba negra pontiaguda e bigode de pontas reviradas, o que distinguia dos outros, que tinham barbas ruivas ou louras. Não sei porquê, essas coisas 
não se explicam, são só intuições, mas me pareceu alguém inofensivo, de fraco caráter, o que era estranho se tratando de um oficial, correndo atrás de aventura e de dinheiro nos mares dos trópicos. (PEPETELA, 1999, p. 103).

De encontros furtivos na lagoa de Kinaxixe surgiu uma gravidez inesperada que o futuro pai huguenote não queria assumir, por causa das diferenças religiosas, conforme relata Matilde à sua irmã Catarina:

Os pais dele fugiram de França e se instalaram na Holanda, porque foram perseguidos pelos católicos. Muitos foram mortos, os que não tiveram tempo de escapar. Os huguenotes são calvinistas como os flamengos, mas franceses. A maior parte dos franceses são católicos e perseguem os das outras religiões, como fazem os portugueses e espanhóis. O Jean não liga muito à religião dos pais, mas também não se pode converter à nossa, que diriam os holandeses? Por isso não podemos casar. (PEPETELA, 1999, p. 116 e 117).

As terríveis reminiscências da noite de São Bartolomeu em Paris (1572) são narradas para Catarina, uma moça católica iletrada, que não podia entender a dimensão da guerra civil entre cristãos, na Europa, e a recusa de Jean em se casar com Matilde, na África. Inquieta questiona a irmã sobre a reação de Jean ao saber da notícia da gravidez:

Mas ficou tão assustado! Que os mafulos o põem fora do exército, porque vai trair a religião que levou os pais a escolher a Holanda. Que eu podia renegar o catolicismo e o predikant casava-nos rapidamente. Aí eu apertei os cabrestos. Eu sou de família importante e católica, nunca vou renunciar à minha família, a dele é que fugiu da sua terra, a minha família nunca fugiu de nada [...]. (PEPETELA, 1999, p. 117).

O impedimento religioso, ou seja, que deveria ser anulado pela conversão de um membro católico para a igreja huguenote, como exigia Jean Du Plessis, para a realização do matrimônio com bênçãos espirituais, abalou a moça:

Mas louca mesmo estava Matilde, pois Jean Du Plessis ameaçara fugir, se matar, tudo fazer, menos casar. Não gostava dela? Adorava-a, era evidente. Mas tinha medo de perder o emprego de mercenário, se traísse a palavra de Calvino, Só de pensar que iria entrar em um templo papista, dos mesmo que mataram tantos dos companheiros dos seus pais, um nó se formava na barriga, não parava de vomitar. (PEPETELA, 1999, p. 121). 
O pobre rapaz evitava o casamento por dois motivos: pelo receio de perder o posto de oficial do exército de linha calvinista, e pelas recordações sobre aquela horrível noite parisiense, na qual seus irmãos de crenças foram caçados como animais, encurralados, aterrorizados e assassinados, expostos à sanha vingativa de desconhecidos católicos e, em consequência da carnificina seus pais tiveram que fugir para a Holanda.

Com a barriga a crescer cada vez mais, Matilde revelou o fato ao pai, explicando as exigências do namorado Jean Du Plessis para contrair matrimônio:

-Casa, se for pelo rito calvinista. Mas eu não quero.

-Mas casa ou não casa?

-Já disse, pai. Se for pela Igreja dele.

-Mas isso não é casamento!

-Foi o que lhe disse. (PEPETELA, 1999, p. 129).

Tresloucado, Baltazar Van Dum rumou até a sede da Companhia das Índias Ocidentais, falou com o Major Tack, exigindo ver o tenente Jean Du Plessis, a quem esbofeteou, chacoalhou como se fosse um espantalho e o lançou a parede. Informado sobre a recusa de Jean em contrair matrimônio, o superior o ameaçou com prisão nas masmorras e desterro com ferros nas mãos e nos pés.

Apavorado, o namorado de Matilde esclareceu a Baltazar sua situação religiosa, que o impedia de se casar em uma igreja católica, narrando a respeito do sangue vertido dos huguenotes pela intolerância francesa:

-Eu gosto de sua filha e quero casar com ela, sempre quis. Mas a minha família fugiu da França porque era perseguida pelos papistas. Somos huguenotes. Já ouviu falar da noite de S. Bartolomeu, em que milhares de pessoas foram assassinadas em França apenas porque eram calvinistas? A minha família perdeu muitos membros, mas os meus pais conseguiram escapar para Flandres, onde eu nasci. Os meus avós, tios, primos, todos, todos, foram mortos traiçoeiramente pelos católicos. Como quer agora que case num templo católico? Só por isso não pedi a mão da sua filha. Sabia que a religião nos separava. Quantas vezes lhe falei em sermos casados pelo predikant. Ela não quis, compreendo até. (PEPETELA, 1999, p. 132). 
Jean falava sobre pessoas incitadas a ações irracionais: Ferimentos, torturas, assassinatos e mutilações de cadáveres de seres humanos indefesos em nome de um cristianismo considerado maior e superior: o catolicismo romano. Tentava esclarecer sua firmeza em se unir em matrimônio somente em uma igreja calvinista:

\footnotetext{
-Mas é uma questão de consciência religiosa.

-Não acredito que seja assim tão amarrado à religião dos seus pais.

-Talvez não seja, mas jurei nunca mais por os pés numa igreja papista, são os culpados do massacre de uma família. De facto não sou muito dado a crenças religiosas, o fanatismo me aborrece. Mas nesse ponto não posso ceder. Perderei tudo, e para mim significa perder a vida, sem Matilde não me interessa viver. Mas não entro numa igreja papista. (PEPETELA, 1999, p. 132).
}

Baltazar, entretanto, exigia a reparação da desonra na igreja católica. Para ele outra solução, o casamento calvinista, seria amancebia. Acordado foi que a cerimônia seria realizada por um padre em um local neutro, pois para o futuro sogro: "O importante não é o sítio, o importante é o padre. Ele legitima o matrimônio”. (PEPETELA, 1999, p. 133). Padre Mateus concordou, a contragosto, em celebrar a cerimônia, sem o batizado do noivo, sem homilia e hóstia.

\subsubsection{A traição de Matilde e o fim do casamento}

Casada com Jean du Plessis, Matilde tinha se desinteressado dele e, em conversas com a confidente Catarina, dizia que o mesmo não tinha: "[...] piada nenhuma, coitadinho, lhe falta o jindungo”. (PEPETELA, 1999, p. 146). Na verdade, ela tinha se enfastiado depois da conquista do huguenote e desejava começar uma nova empreitada de descobertas sexuais junto ao oficial holandês Joost Van Koin:

Koin era um maluco, dizia Matilde a rir, um aventureiro.[...] Esperava ansiosamente por uma batalha importante para chegar a capitão, dizia, não saio daqui sem ser capitão. Por contraste, o pobre Jean nem sabia muito bem como conseguira chegar a tenente, se nunca tinha se 
distinguido em nada. E se alistou no exército holandês para fugir à opressão paterna, que o castigava atrozmente para lhe meter na cabeça os santos princípios do calvinismo. Se alistou por fuga a um terror maior, não por uma procura de aventura, comentava amargamente Matilde. (PEPETELA, 1999, p. 146).

O local dos encontros proibidos era na Sé, na Igreja de Nossa Senhora da Conceição, localizada perto da barroca, de onde se podia ver uma bela paisagem: ao sul, a Ilha de Luanda, a barra da Corimba, e ao fundo, o Mussulo, que é um banco de areia de cerca de $30 \mathrm{~km}$ de comprimento. Ansiosa para encontrar o amante, Matilde não se importava com a sujeira da sacristia, pois o templo religioso tinha sido parcialmente destruído durante a invasão holandesa, três anos antes, no ano de 1641.

No recinto mal iluminado e imundo, Joost colocara uma manta, trazida escondida em uma bolsa, e na ansiedade inicial o primeiro interlúdio sexual não fora satisfatório:

Matilde não estava tranquila e o acto de amor se ressentiu da inquietação. Foi tudo muito rápido, a despachar para ir embora o mais cedo possível, os dois a ficarem desiludidos pelo sabor a pouco em face do desejo que nutriam. Se despediram com muitos pedidos de desculpa, da próxima vez será melhor. (PEPETELA, 1999, p. 156).

A igreja em si, que fora escolhida para o local do adultério, tinha uma aura sagrada, e tal atmosfera que pairava no ar, apesar da destruição dos móveis e artefatos religiosos por membros do exército flamengo por ocasião da conquista, não maculara o recinto. Erotismo e sacristia não combinavam e o encontro falhara entre os fogosos amantes:

Por isso, [Matilde] recusou outros encontros, foi adiando, adiando, até que uma semana depois cedeu, o desejo era muito e Joost tão querido, nas tardes de visita a fitava com olhos de cão injustamente castigado, suplicando mais um encontro, só mais um e depois a morte. Ela não podia resistir a tanta paixão. [...] Estava enlaçada a Van Koin, por cima da manta que ele deixara embrulhada num canto da primeira vez, quando fez a irrupção o enganado marido. (PEPETELA, 1999, p. 157). 
Em uma nova tentativa de vivenciar o erotismo, o flagrante acabou com a vida do esposo traído que não se importou com o retorno da esposa e o nenê Henri para a sanzala Van Dum, enquanto que Joost Van Koin, na taverna, se jactava de sua virilidade com Matilde e aguardava um duelo com Jean Du Plessis, o marido destruído que somente bebia para suportar o final de seus sonhos de família feliz.

Baltazar Van Dum tentava contornar a situação, exigindo do esposo traído a reparação da honra perdida de sua família, em um confronto com armas com o amante de sua esposa Matilde:

\begin{abstract}
-Por quem me toma, senhor Van Dum? Agora vou representar o papel do marido vingativo, só para salvar uma carreira militar que sequer me interessa por aí além? E sabendo que tudo é uma encenação? Agradeça muito ao major, mas não sou hipócrita. O Van Koin vai para o Brasil? Que vá. Não me interessa. Ainda não percebeu que o problema não é esse? [...] -O problema, senhor Van Dum, é que a sua filha me traiu. Esse é o problema. O resto não conta. (PEPETELA, 1999, p. 170).
\end{abstract}

Convicto da necessidade de restaurar o matrimônio de Matilde, jovem mãe de Henri, que tinha dois meses de idade, o pai luta com vários argumentos, a fim de convencer o genro huguenote de que o casamento católico era um sacramento que somente terminaria com o falecimento de um dos cônjuges:

-Se quer salvar o seu casamento, tem de salvar primeiro a sua carreira. E para a salvar tem de fingir que vai desafiar o bandido para um duelo. Salve o seu casamento, porra, seja homem.

- Já morreu, bolas. Esse casamento acabou só falta enterrar. [...].

- Desculpe, mas não é assim. Casamento católico é para toda a vida. Esqueceu que se casou pela regras da Igreja Católica? [...]

- Que quer dizer?

- Que está casado com a minha filha e estará casado até que algum de vocês morra. E por isso tem responsabilidades. Uma delas é prover às necessidades dela e do vosso filho. (PEPETELA, 1999, p. 170 e 171).

Irredutível, Jean Du Plessis se posiciona como huguenote e desdenha da celebração matrimonial realizada pelo padre Mateus, desafiando o sogro, o qual defendia a indissolubilidade do casamento católico: 
-Não sei como é com os católicos, nem me interessa. A cerimônia com o padre foi apenas um estratagema. O que importa é que a sua filha me traiu. Acha que tem sentido manter um casamento, depois disso, só porque ele foi celebrado por um padre? Tenho de ficar todos os dias a reabrir a ferida, sempre que olhar para ela, ou a ouvir? Para satisfazer a sua religião, ou uma religião qualquer? Não, senhor Van Dum, o senhor não tem o poder de me obrigar a manter o casamento que já morreu.

-Tenho, sim. Vou mandar a Matilde voltar para esta casa. O que você pense não me interessa. Nem o que vocês façam por trás das paredes, até Mas ficam aqui a viver juntos, como um casal. Por isso casaram. (PEPETELA, 1999, p. 171).

Jean reafirma sua identidade calvinista, enfatizando que Luanda era território holandês com legislação própria, no qual não havia um mecanismo coercitivo que enquadrava pessoas que decidiam assuntos de foro íntimo. Ele criticava a colonização portuguesa, bem como a engrenagem repressora do tribunal da devassa católica, que não tolerava outras tendências no cristianismo, condenando seus membros como hereges:

-Não nos pode forçar a viver juntos, isso não é um Estado católico. Aqui as leis são as das Províncias Unidas da Holanda, não são as de Portugal. Não tem aqui a Inquisição para me obrigar. Esqueça, senhor Van Dum, esqueça. (PEPETELA, 1999, p. 170 e 171).

Defensor férreo do matrimônio, considerado um sacramento no catolicismo desde o Concílio de Trento, Baltazar Van Dum dirigiu-se, novamente, ao Major Tack para pedir ajuda, narrando: “- O tenente diz que o casamento terminou. Como se isso fosse possível. É um casamento pela Igreja Católica, perpétuo portanto”. (PEPETELA, 1999, p. 172). Diante da recusa do militar em se envolver no conflito, Baltazar disse a ele sobre seus planos de solicitar a ajuda do diretor Molt, mas foi advertido por Tack a não concretizar o intento:

O Hans Molt simplesmente não os reconhece como casados. Deixou a coisa correr, porque sabia que eu me envolvi em boa medida no assunto. Mas, disse-me, o que anda agora a fazer em casamentos falsos, metendo um huguenote e uma católica, com um padre que pertence a outra jurisdição? Sabe como ele é meticuloso nas coisas burocráticas. O padre Mateus pode oficiar em território congolês, como é na Ilha de Luanda. Mas não aqui, que é território holandês. Em termos legais, esse casamento nunca existiu. É isso que ele vai lhe dizer. E terá prazer em lhe atirar à cara que o seu genro é livre de fazer o que quiser. (PEPETELA, 1999, p. 173). 
O Major Tack tentava persuadir Baltazar a aceitar a separação do casal, cuja união somente foi tolerada pela alta hierarquia holandesa para evitar comentários:

Hans Molt é um funcionário fanático e rígido, que apenas se preocupa com o lucro de seus patrões. Sem agir contra os princípios de Calvino, claro. Acredite, não houve casamento capaz de ser legal, esse é o pensamento do director, o qual nunca aceitaria que um calvinista participasse de um ritual católico. Fechou os olhos na altura, porque Jean $\mathrm{Du}$ Plessis se prestou apenas a uma farsa, no seu próprio interesse e provavelmente no da Companhia, que não estava interessada em escândalos. (PEPETELA, 1999, p. 173).

No confronto entre o huguenote Du Plessis e o católico Van Dum sobre a (in)dissolubilidade do matrimônio, duas ideologias cristãs se revelaram intolerantes uma com a outra.

O amante de Matilde, Joos Van Koin, frequentador dos animados encontros socioculturais, a base de chá de caxinde na residência do jovem casal, onde a seduzia com olhares e palavras, em evidente desrespeito ao esposo e ao filhinho, era um falastrão. Exímio espadachim e militar, que se vangloriava da conquista de Matilde e buscava um duelo, foi deportado de Luanda no navio Leyden rumo ao Brasil, onde seria rebaixado à condição de soldado por não saber se comportar como um cavalheiro.

O casamento católico indissolúvel de Matilde e Jean tinha terminado na opinião do marido desonrado que não queria lutar com o rival, tampouco reconciliar com a esposa adúltera. Para contornar o desinteresse do tenente Du Plessis em resgatar a sua honra perdida foi pensado na sua transferência para $o$ comando de um forte do rio Kwanza, mas como ele era considerado um frouxo, foi descartado o projeto. Informado sobre a possibilidade de Jean ser enviado para uma feitoria holandesa de apoio à navegação no Oriente, Baltazar começou a gritar: "E o meu problema não se resolve [...] que fico com uma filha casada, mas sem marido, impossibilitada, portanto, de se casar com outro". (PEPETELA, 1999, p. 177). 
Aniquilado com o casamento destruído, o huguenote sabia que todos esperavam que ele pegasse nas armas para defender sua honra, mas, ele optou por embarcar no navio De Princesse que naufragou por causa de colisão com os rochedos do Cabo da Boa Esperança.

Viúva estava Matilde Van Dum, a causadora de tantas desgraças, que não foi poupada das críticas, pois ela cometeu uma grave violação dos deveres conjugais e maternais, principalmente, pois a prática de adultério era criminalmente mais grave quando praticado pela mulher.

\section{Conclusão}

No romance $A$ Gloriosa Família: No tempo dos flamengos (1997), no qual Pepetela evoca a presença colonialista dos holandeses calvinistas em Luanda, nos anos 1641 a 1648, bem como o episódio horrendo da perseguição, matança dos protestantes franceses na noite de São Bartolomeu (1572) e a dispersão dos sobreviventes que são rememorados pelo tenente huguenote, Jean Du Plessis, em tensas conversas com Matilde e Baltazar van Dum. Os temas foram a celebração religiosa do matrimônio e a separação, pleiteada por Jean, o marido traído.

No episódio sobre as relações amorosas e de fidelidade entre o casal Du Plessis e Van Dum emerge a compreensão distinta do cristianismo ocidental no século XVI: A igreja protestante de tradição calvinista, vivenciada pelos huguenotes, tinha uma compreensão específica sobre o matrimônio com a possibilidade do divórcio, em contraposição à igreja católico-romana que estabeleceu no Concílio de Trento (1545-1563) que o sacramento do casamento não poderia ser rompido.

No artigo Por uma filosofia do casamento, José Rômulo de Magalhães Filho pondera a respeito das distintas concepções religiosas sobre a união entre o homem e a mulher: 
A indissolubilidade do matrimônio defendida teologicamente pela teologia católica romana [...] tem levado muitos casais a viverem relações familiares turbulentas, cheias de conflitos pessoais. Muitos se afastam de sua comunidade religiosa para sentirem-se menos culpados, o quê não possibilita uma criação dos filhos nos mesmos padrões sócio-religiosos. Se o protestantismo histórico, com a possibilidade do divórcio, banaliza para alguns o matrimônio, o catolicismo romano, através da visão de relação indissolúvel, escraviza o indivíduo, que levado por alguma ação não é feliz no seu matrimônio. $\mathrm{O}$ que pode atingir todo seu agir como ser social. (MAGALHÃES FILHO, s.d., p. 8).

Compreende-se que, a liberdade de escolha postulado pelo protestantismo em relação ao casamento e sua continuidade não existe no catolicismo romano, o que provoca um tipo de escravidão e infelicidade na família. Tal assertiva pode ser constatada no romance A Gloriosa Família, de Pepetela, com foco em duas famílias desonradas por causa de um adultério feminino: De um lado, a família de Jean Du Plessis, infeliz huguenote, pai de Henri, que tinha cerca de dois meses, quando sua mãe se tornou infiel. E, de outro, a família Van Dum, católica tradicional, que acreditava na indissolubilidade do casamento e que minimizou o mau passo de Matilde, apelando para que Jean defendesse a honra com um duelo com o seu inimigo e mantivesse a união.

Em Luanda, no ano de 1644, Jean Du Plessis, oficial huguenote da Companhia das Índias Ocidentais, entretanto, apela para sua consciência e para sua liberdade de escolha, baseadas na essência da teologia calvinista que admite o divórcio em prol da saúde física, mental, familiar e social de um relacionamento humano frustrado com ou sem filhos.

A posição determinada e até mesmo empedernida do jovem oficial huguenote revelou que ele não aceitou duelos nem reconciliações para a salvação do casamento, pois a confiança em sua esposa arrefeceu, sem possibilidades de renovação. Sua conclusão, a respeito da urgência do divórcio, explicada ao seu sogro, choca o clã mestiço dos Van Dum, que não admite separação, mesmo se tratando de uma falta feminina como a provocada por Matilde, jovem esposa e mãe, que não foi castigada, com nenhuma forma de sanção, nem pelos irmãos nem 
pelo genitor e seguiu sua vida com o nenenzinho Henri, depois nomeado de Henrique, na sanzala da família.

\section{REFERÊNCIAS}

ANTIGO TESTAMENTO. Disponível em:

<http://www.bibliaon.com/antigo_testamento/>. Acesso em: 12 mai. 2016.

BERGSTEDT, Axel. Os sacramentos. In: BERGSTEDT, Axel. Parábolas e outras obras. Disponível em:<http://axelbergstedt.blogspot.com.br/2010/04/os-sacramentos.html >. Acesso em: 12 mai. 2016.

BRIGGS, Asa et alii. Der Streit in den inneren Frieden in Frankreich. In: BRIGGS, Asa et alii. Chronik de Weltgeschichte: Die dramatischen Ereignisse der Geschichte und wie sie die Welt veränderten. Stuttgart: Verlag Das Beste, 1996. p. 136 e 137.

BRIGGS, Asa et alii. Eine Hochzeit kostet Tausend das Leben. In: BRIGGS, Asa et alii. Chronik de Weltgeschichte: Die dramatischen Ereignisse der Geschichte und wie sie die Welt veränderten. Stuttgart: Verlag Das Beste, 1996. p. 134 e 135.

DELUMEAU, Jean. Angst in Abendland: Die Geschichte kollektierter Ängste im Europa des 14. bis 18. Jahrhunderts. Hamburg: Rowohlt, 1989.

FRANÇOIS DUBOIS. Disponível em:

<http://pt.wikipedia.org/wiki/Fran\%C3\%A7ois_Dubois>. Acesso em: 12 mai. 2014.

GOMES, António M. de Araújo. O Pensamento de João Calvino e a Ética Protestante de Max Weber, Aproximações e Contrastes. Fides Reformata, São Paulo, v. 7, n. 2, p. 1-20, 2002.

GUIMARÃES, Elias L. Família e a dinâmica da socialização. Veritati, Salvador, ano II, n. 2, p. 55-64, jul. 2002.

GUTHRIE JR., Shirley C. Para uma teologia do casamento cristão. In: MCKIM, Donald (Ed.). Grandes temas da tradição reformada. São Paulo: Pendão Real, 1988. p. 288293.

HUTCHEON, Linda. Poética do Pós-Modernismo: história, teoria, ficção. Tradução de Ricardo Cruz. Rio de Janeiro: Imago, 1991.

IGREJA PRESBITERIANA INDEPENDENTE DO BRASIL. A confissão de fé e o catecismo maior. São Paulo: CEP, 1991.

MAGalHães FILHO, José Rômulo de. Por uma filosofia do casamento. Disponível em: <http://jrmf.pro.br/filmatr.pdf>. Acesso em: 12 mai. 2016. 
MASSACRE DA NOITE DE SÃO BARTOLOMEU. Disponível em: <http://pt.wikipedia.org/wiki/Massacre_da_noite_de_S\%C3\%A30_Bartolomeu>.Acesso em: 12 mai. 2016.

MATA, Inocência. Pepetela e as (novas) margens da nação angolana. Veredas: Revista da Associação Internacional de Lusitanistas, n. 4, p. 133-145, dez. 2001. Disponível em: <http://revistaveredas.org/index.php/ver/article/view/182>. Acesso em: 15 ago. 2016.

MELLO, Carlos. A noite de São Bartolomeu: O massacre abençoado. 2012. Disponível em:

<http://www.ricardoorlandini.net/colunistas/ver/47/37851/a_noite_de_sao_bartolomeu _o_massacre_abencoado/>. Acesso em: 12 mai. 2016.

MENEZES, Sezinando L.; SANTOS, Thiago C. dos. Os holandeses e o nordeste brasileiro: 1630-1654. In: Anais do XIX Encontro Regional de História: Poder, Violência e Exclusão, p. 1-9. ANPUH/SP-USP. São Paulo, 2008. Disponível em:

<http://www.anpuhsp.org.br/sp/downloads/CD\%20XIX/PDF/Paineis/Thiago\%20Cavalc ante\%20dos\%20Santos.pdf>. Acesso em: 12 mai. 2016.

OHLIG, Rudolf. Humanismus und Reformation: Erasmus und Luther. In: DIGEL, Werner (Org.). Meyers Illustrierte Weltgeschichte. Augsburg: Weltbild Verlag, 1987. p. 136142.

OS HUGUENOTTES, opereta de Octávio Rangel e música de Carlos de Carvalho. O Paiz, 11 de abril de 1926. Disponível em:<http://memoria.bn.br/docreader/DocReader.aspx?bib=178691_o5\&pagfis=24942\&p esq=\&esrc $=$ s $>$. Acesso em: 12 mai. 2016.

OS SETE SACRAMENTOS. Disponível em:

<http://www.catolicoorante.com.br/7sacramentos.html>. Acesso em: 12 mai. 2016.

PEPETELA. A Gloriosa Família: O tempo dos Flamengos. Rio de Janeiro: Nova Fronteira, 1999.

RAMME, Oliver. 1572: A noite de São Bartolomeu. Deutsche Welle. Disponível em: <http://www.dw.de/1572-a-noite-de-s\%C3\%A3o-bartolomeu/a-320214>. Acesso em: 12 mai. 2016.

SCOLA, Ângelo. O mistério nupcial. Trad. de Maria de Lourdes Lima. Bauru: EDUSC, 2003.

VASARI, Giorgio. O Mural de Vasari. Disponível em: <http://pt.wikipedia.org/wiki/Massacre_da_noite_de_S\%C3\%A30_Bartolomeu\#mediavi ewer/File:Giorgio_Vasari_San_Bartolomeo.jpg>. Acesso em: 12 mai. 2016. 